\title{
Accountability, Legitimacy, and Voluntary Tax Compliance: A Case Study in Tax Offices in Mazandaran Province of Iran
}

\author{
Mohammad Reza Sobhkhiz ${ }^{1}$, Ali Mehdizadeh Ashrafi ${ }^{2}$, Toraj Mojibi ${ }^{3}$, Mahmood Otadi ${ }^{4}$
}

${ }^{1}$ Department of management, Firoozkooh Branch, Islamic Azad University, Firoozkooh, Iran
$2^{2 *}$ Department of management, Firoozkooh Branch, Islamic Azad University, Firoozkooh, Iran
${ }^{3}$ Department of management, Firoozkooh Branch, Islamic Azad University, Firoozkooh, Iran
${ }^{4}$ Department of Mathematics, Firoozkooh Branch, Islamic Azad University, Firoozkooh, Iran

Keywords:

Accountability, Legitimacy, Voluntary Tax Compliance

\section{Received}

24 May 2020

Received in revised form

23 June 2020

Accepted

27 June 2020

\begin{abstract}
This study investigates the impact of the tax system's accountability on improving taxpayers' voluntary tax compliance through influencing taxpayers' perceived legitimacy in tax offices in Mazandaran province of Iran. The accountability is here taken as 'responsiveness'. Adopting mixed methods design, the Delphi technique was first used to identify the legitimate expectations and demands of taxpayers. In the second step, 4 types of accountability mechanisms were identified as the components of overall accountability. In the third step, using partial least squares path modeling via Smart PLS software, the impact of the tax system's accountability on the perceived legitimacy of the tax system as well as the impact of perceived legitimacy of the tax system on voluntary tax compliance was tested. The obtained results indicated that the tax system's accountability affects voluntary tax compliance through influencing taxpayers' perceived legitimacy of the tax system. Furthermore, political and social accountability was not at the optimal level and the optimality of managerial and legal accountability did not have a significant impact on voluntary tax compliance. Finally, it is suggested that to improve the perceived legitimacy of the tax system. As the results of voluntary tax compliance showed, more attention should be paid to the mechanisms of political accountability in the political sector and social accountability in both the political and administrative sectors of the tax system.
\end{abstract}

\section{Introduction}

Accountability has become a cornerstone of current discussion on the prospects of legitimate and effective global governance (Rached, 2016). As a two-dimensional concept, accountability carries two basic connotations: answerability, the obligation of public officials to inform about and to explain what they are doing; and enforcement, the capacity of accounting agencies to impose 
sanctions on power holders who have violated their public duties (Schedler, Diamond, \& Plattner, 1999). In contemporary political and scholarly discourse, 'accountability' often serves as a conceptual umbrella term that covers the other various distinct concepts such as transparency, equity, democracy, efficiency, responsiveness, responsibility, and integrity. Such very broad conceptualisations of the concept make it very difficult to establish empirically whether an official or organization is subject to accountability, because each of the various elements needs extensive operationalisation itself and because the various elements cannot be measured with the same scale (Bovens, 2007). In this paper, accountability is taken as 'responsiveness'. In this concept, 'accountability' is linked with the extent to which governments pursue the wishes or needs of their citizens (accountability as 'responsiveness') regardless of whether they are induced to do so through processes of authoritative exchange and control (Mulgan, 2000). Responsiveness, in the context of public administration, is the perception by individual citizens as how public administration can include the demands of the citizen and how effectively public administration has succeeded in implementing these demands in their decisions (Rolle, 2017).

The low level of voluntary tax compliance imposes many costs on tax systems to identify and assess taxable income and to claim and collect taxes. Current statistics ${ }^{1}$ indicate that there is a significant difference between the amount of the tax expressed in the tax returns of taxpayers and their assessed taxes. The field study also suggests that many taxpayers are unwilling to pay their obligations. They do not accept tax rates and do not approve of the way collected taxes are allocated and they question informing and investigation processes. The concept of legitimacy refers to perceptions by key stakeholders that the existence, activities, and impacts of civil society organizations are justifiable and appropriate in terms of central social values and institutions (Brown \& Jagadananda, 2007). It seems that these taxpayers do not have a sense that the tax system is lawful, admissible, and justified in its chosen course of action. The work of tax authorities would resemble a customer-oriented service being provided to help and support taxpayers to fulfill their duties (Muehlbacher, Kirchler, \& Schwarzenberger, 2011). The field study shows that taxpayers have legitimate expectations and demands, and ask for responsiveness in some cases which has not been satisfied. Responding to these expectations and demands, for example, "the fair allocation of tax revenues to different classes of society" is not at the discretion of a tax official at the operational level, and is in the area of authority of policymakers, outside the tax administration. In the present study, it has been assumed that responding to legitimate expectations and demands of taxpayers by accountability mechanisms, through influencing tax systems' legitimacy, enhances their voluntary tax compliance. This has not been investigated in one single article in its present form in prior studies. The novelty of this article lies in the specification and development of a conceptual model in which both the accountability of actors in the administrative sector of the tax system, including tax managers and other tax officials and the accountability of tax policymakers who are actors in the political sector of the tax system are taken into account, as well as four dimensions of legitimacy corresponding to the accountability mechanisms identified.

\footnotetext{
1. The ratio of tax declared in tax returns to the assessed tax of individual businesses in 2012 is $10.6 \%$, in 2013 $14.8 \%$, in $201415.5 \%$, in $201521 \%$, and on average during these four years, it is $15.5 \%$. These figures show a low level of tax compliance, with the Tax Offices' assessed tax being approximately 6.5 times the taxpayer's declared tax in tax returns (Individual Businesses Database of Iranian National Tax Administration, 2018).
} 


\section{Accountability}

Much of the academic literature on accountability is rather disconnected, and many authors set out to produce their own specific definitions of accountability (Brandsma \& Schillemans). According to Mulgan (2000), the scope and meaning of 'accountability' has been extended in a number of directions well beyond its core sense of being called to account for one's actions. Bovens (2010) distinguishes between two main concepts of accountability: accountability as a virtue and accountability as a mechanism. The former accountability is used primarily as a normative concept, as a set of standards for the evaluation of the behavior of public actors. Accountability or, more precisely, being accountable, is seen as a positive quality in organizations or officials. Often, in this type of discourse, the adjective 'accountable' is used, as in: 'the public officials should be accountable', 'accountable governance', or 'government has to behave in an accountable manner' (Akpanuko \& Asogwa, 2013). Koppell (2005) also categorized five different dimensions of accountability as a virtue -transparency, liability, controllability, responsibility, and responsiveness-, as presented in Table 1:

Table 1

Five Conceptions of Accountability

\begin{tabular}{ll}
\hline Conceptions of Accountability & Key Determination \\
\hline transparency & Did the organization reveal the facts of its performance? \\
liability & Did the organization face consequences for its performance? \\
controllability & Did the organization do what the principle ordered? \\
responsibility & Did the organization follow the rules? \\
responsiveness & Did the organization fulfill expectations? \\
\hline
\end{tabular}

As a mechanism, accountability is used in a narrower, descriptive sense. It is seen as an institutional relation or arrangement in which an actor can be held to account by a forum. Here, the focus of accountability studies is not the behavior of public agents, but the way in which these institutional arrangements operate (Bovens, 2010). In this sense, Bovens (2007) says accountability is a relationship between an actor and a forum, in which the actor has an obligation to explain and to justify his or her conduct, the forum can pose questions and pass judgment, and the actor may face consequences.

Researchers have classified accountability as a mechanism in a variety of ways. Romzek and Dubnick (1994) classified accountability into four categories based on the source and degree of control in public agencies: bureaucratic, professional, legal, and political. Sinclair (1995) categorized five forms of accountability: political, public, managerial, professional, and personal. Bovens (2007) has categorized accountability as a mechanism based on 1) the nature of the accountability forum, 2) the nature of the actor, 3) the nature of the conduct, and 4) the nature of the obligation, as described in Table 2:

Table 2

Types of Accountability

\begin{tabular}{llll}
\hline $\begin{array}{l}\text { Based on the nature of the } \\
\text { obligation }\end{array}$ & $\begin{array}{l}\text { Based on the nature of the } \\
\text { conduct }\end{array}$ & Based on the nature of the actor & $\begin{array}{l}\text { Based on the nature of the } \\
\text { forum }\end{array}$ \\
\hline $\begin{array}{l}\text { Vertical accountability } \\
\text { Diagonal accountability }\end{array}$ & $\begin{array}{l}\text { Financial accountability } \\
\text { Procedural accountability }\end{array}$ & $\begin{array}{l}\text { Corporate accountability } \\
\text { Hierarchical accountability } \\
\text { Collective accountability } \\
\text { Individual accountability }\end{array}$ & $\begin{array}{l}\text { Political accountability } \\
\text { Product accountability }\end{array}$ \\
\end{tabular}




\section{Legitimacy}

Deephouse and Carter (2005) view legitimacy as the social acceptance resulting from adherence to regulative, normative, or cognitive norms and expectations. Legitimating arguments invoking shared legitimacy beliefs imply a socially sanctioned obligation to comply with government policies even if these violate the actor's own interests or normative preferences and even if official sanctions could be avoided at low cost (Scharpf, 2003). Legitimacy is a concept meant to capture the beliefs that bolster willing obedience (Levi, Sacks, \& Tyler, 2009) and low levels of legitimacy are often behind a state's inability to ensure compliance (Di John, 2006). According to Tyler (2006), because of legitimacy, people feel that they ought to defer to decisions and rules, following them voluntarily out of obligation rather than out of fear of punishment or anticipation of reward. When citizens recognize the legitimacy of an authority they believe that the authority has the right to prescribe and enforce law-abiding behavior (Murphy, Bradford, \& Jackson, 2016). Also, underlying organizational legitimacy is a process, legitimation, by which an organization seeks approval (or avoidance of sanction) from groups in society (Kaplan \& Ruland, 1991). Level of congruence between corporation's activities and expectations of that particular corporation's activities is a direct reflection of its legitimacy (Marvin, Marilou, \& Max, 2017).

The study of theoretical foundations suggests the positive impact of accountability on legitimacy. Accountability as a virtue is important because it provides legitimacy to public officials and public organizations. Accountability as a mechanism is also important because it contributes to the legitimacy of public governance (Bovens, 2010). Alison Young draws on Mark Bovens definition of accountability and on a broader view of accountability as incorporating a normative dimension via the notions that a body which can be held to account for its actions is more legitimate than one which cannot and that any practice which enhances accountability enhances legitimacy (Bamforth \& Leyland, 2011 ). Improving accountability to appropriate stakeholders can strengthen Civil Society Organizations (CSO) legitimacy by clarifying the interests they serve and how abuses can be controlled (Brown, \& Jagadananda, 2007). Responsiveness is linked with the idea of pragmatic legitimacy. The organization failing to meet the demands of constituents can hardly get passing grades on any test of interest satisfaction. Such failures of responsiveness-type accountability are experienced as losses of pragmatic legitimacy (Koppel, 2010).

Studies also show that perception of legitimacy generally enhances voluntary compliance (Gezelius, 2002; Honneland, 2000; Stern, 2008; Tyler, 1990; Tyler \& Fagan, 2008; Viteri \& Chavez, 2007). Tyler (1990) in his research revealed that legitimacy includes multiple facets that are important to different people in different situations. He showed that legitimacy can be influenced by social relations (the influence of other people's judgments), normative values (person's own ethical views), consistent adequate performance of the authority, procedural justice, and distributive justice.

Few empirical kinds of research have been conducted on the impact of accountability on legitimacy. For example, Koppel (2010) found a positive relationship between the transparency aspect of accountability and legitimacy. He also added other variables that might affect legitimacy, such as empowerment and decision-making processes. Although these variables affected legitimacy, the relationship between accountability and legitimacy was much profound. Wareman (2013) defines accountability as the extent that an organization provides information to its stakeholders. The findings indicated that, contrary to the research hypothesis, although there was a 
significant relationship between accountability and legitimacy, high levels of accountability were associated with low levels of legitimacy.

\section{Voluntary Tax Compliance}

Tax compliance represents a social dilemma in which the short-term self-interest to minimize tax payments is at odds with the collective long-term interest to provide sufficient tax funds for public goods (Gangl, Hofmann, \& Kirchler, 2015). Andreoni, Erard, and Feinstein (1998) define tax compliance as an individual's willingness to pay his obligation. Roth, Scholtz, and Witte, (1989) define tax compliance as compliance with reporting requirements implying timely filing of returns and reporting accurate tax liability in accordance with the internal revenue code, regulations, and court decisions applicable at the time return filing. This definition assumes that in order to comply with the tax law, one must declare the correct amount of income, expenses to which one is entitled, and subsequently pay the correct amount of tax by the due date (Tilahun, 2018).

In the literature on tax compliance, two different approaches are identifiable. The researches have indicated that tax compliance is attributable to the factors which are economic or psychological (Muehlbacher et al., 2011). The economic approach to tax compliance (Allingham $\&$ Sandmo, 1972; Becker, 1968) assumes that the threat of sanctions (i.e. fines) shapes taxpayers' behavior. Here a rational individual is viewed as maximizing the expected utility of the tax evasion gamble by weighing the benefits of successful cheating against the risky prospect of detection and punishment. Through this process, an outcome is reached where the individual pays taxes because he or she is afraid of getting caught and penalized if he or she does not report all income (Torgler, 2011). On the other hand, in a psychological or behavioral approach, researchers have considered examining taxpayers' inner motivations, beliefs, perceptions, attitudes in order to accurately predict taxpayers' behavior (Batrancea et al., 2012). One of the most important psychological factors that shape voluntary tax compliance is the perceived legitimacy of authorities (Van Dijke et al., 2019., Gobena, 2017; Jagers, Matti, \& Nordblom, 2016; Levi et al., 2009; Wahl, Kastlunger, \& Kirchler, 2010; Wenzel \& Jobling, 2006). Where legitimating beliefs exist, citizens would accept that the state has the right to impose taxes, and tax compliance is likely to become more habitual.25 Conversely, the less citizens consider the government to be legitimate, the less they will accept their obligation to give it the taxes it needs to govern (Aboagye \& Hillbom, 2020). The need to examine the issue of voluntary tax compliance as a subset of the broader body of knowledge on tax compliance as emerged, motivated by the inadequacies of the prevailing orthodoxies on tax compliance to capture the proportion of total compliance not accounted for by economic models (Modugu, Eragbhe, \& Izedonmi, 2012).

Jagers et al. (2017), using unique panel data through the three phases of the congestion tax in the Swedish city of Gothenburg, investigated the importance of legitimacy and compared how drivers of public policy attitudes would evolve across the policy process. Their research findings indicated that legitimacy was indeed important in explaining policy support. Moreover, they found a lingering effect where support in one phase is dependent on legitimacy both in the present and in previous phases. Levi et al. (2009) take legitimacy as a sense of obligation or willingness to obey authorities (value-based legitimacy) that then translates into actual compliance with governmental regulations and laws (behavioral legitimacy). Their findings indicated considerable evidence of a link between the extent of the trustworthiness of government and procedural justice and citizens' willingness to defer to the police, courts, and tax department in a wide range of African societies. 
Gobena (2017) in his research prepared the survey and collected data from Ethiopian taxpayers in person and US taxpayers via AMT and examined the legitimacy of the tax authority as a boundary condition for the interactive effect of procedural and distributive justice on voluntary tax compliance. He concluded that tax authorities should either be high in legitimacy to be able to secure taxpayers' voluntary compliance without reference to trust and justice concerns or be sufficiently coercive to the extent that taxpayers would seek to avoid strict measures. Van Dijke et al. (2019) explored the roles of procedural and distributive justice and citizens' perceptions of the tax authority's power in stimulating voluntary tax compliance. They considered power combined with procedural and/or distributive justice (which involves legitimization and offering information) provides an encompassing index of the legitimacy of tax authorities. They concluded that distributive and procedural justice and justice are both factors that enhance voluntary tax compliance.

In the present study, four types of political, managerial, legal and social accountability mechanisms were selected using the classification of Bovens' accountability Types (2007) based on the nature of the accountability forum, and according to the literature of the subject, the following operational definitions were made. Political accountability refers to the accountability of elected representatives to voters. In fact, elected representatives in parliament or other legislative institutions are policymakers who, because of establishing laws and regulations for solving public issues such as establishing laws on tax rates or allocation of collected taxes, etc. in the tax system, must be held accountable to voters during the election. Managerial accountability refers to the accountability of managers and staff of the public administration who are under formal obligation to render account about their "performance" to their superiors. In fact, managers and employees of the public sector implement the laws enacted by public policymakers. Legal accountability refers to the accountability of public managers and staff who are under formal obligation to render account to administrative or judicial courts in relation to the observance and enforcement of laws. Social accountability refers to the accountability of policymakers, public managers, and staff about their performance to the public at large or at least to clients, interest groups, associations of clients, media, and so on. In this type of accountability, the actors are not under formal obligation to render account and account-holders lack the possibility of sanctioning them. Legitimacy refers to the acceptance and approval of the tax system's procedures or tax authorities' activities when doing their social, managerial, political, and legal duties. The level of congruence between the tax system's activities and expectations of those activities is a direct reflection of its perceived legitimacy. Corresponding to the four types of accountability identified, the four political, managerial, legal, and social dimensions are considered dimensions of the legitimacy of the tax system. Voluntary tax compliance refers to taxpayers' willingness to pay taxes and is differentiated between moral and practical willingness to pay taxes. The moral dimension of voluntary tax compliance refers to the intension of the taxpayer to pay taxes voluntarily and the practical dimension of voluntary tax compliance refers to the actual behavior of paying taxes voluntarily. Finally, by examining theoretical foundations and empirical research, the following conceptual model, as demonstrated in Figure 1, was developed: 


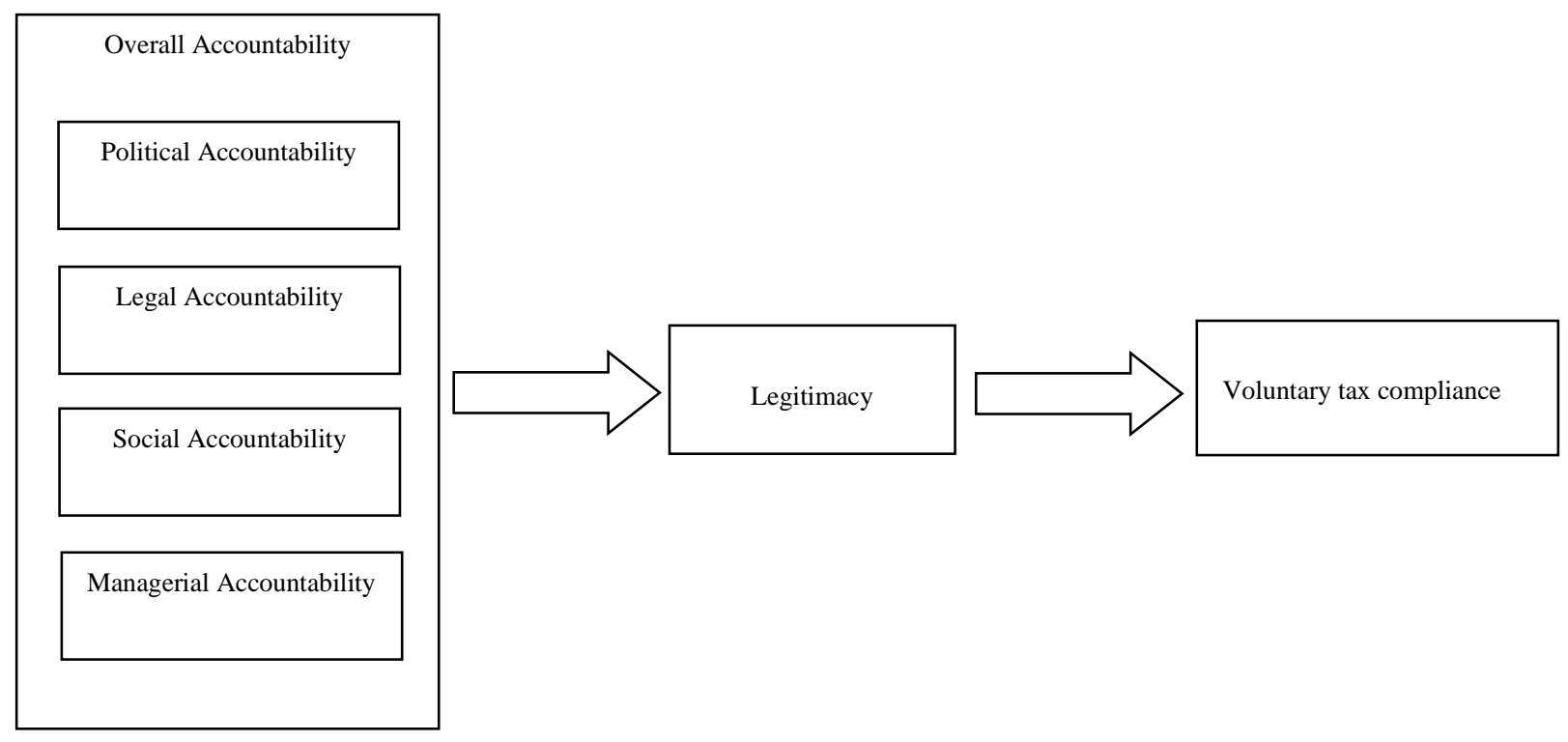

Figure 1. The conceptual model

The research questions are developed as follows:

1. What are the legitimate expectations and demands of taxpayers from policymakers, tax managers, and other tax officials?

2. What are the accountability mechanisms of policymakers, tax managers, and other tax officials?

3. Does the accountability of the tax system have a positive impact on taxpayers' perceived legitimacy?

4. Does the taxpayers' perceived legitimacy of the tax system have a positive impact on their voluntary tax compliance?

\section{Method}

Since the present study is a mixed type, the researchers incorporated methods of collecting or analyzing data from the quantitative and qualitative research approaches in a single research study. Qualitative research builds its premises on inductive, rather than deductive reasoning. That is, researchers collect or analyze not only numerical data, which is customary for quantitative research but also narrative data, which is the norm for qualitative research in order to address the research question(s) defined for a particular research study (Williams, 2007). In the first step, in order to answer the first and second questions of the research, the Delphi technique was used to identify the legitimate expectations and demands of taxpayers from policymakers, tax managers, and other tax officials. Data collection was conducted through semi-structured interviews and 3 open-ended questions -the first question of the research- in three phases. The data were analyzed inductively so that the researchers reached some sort of final summing up. Then based on the conceptual model and operational definitions of the research and also the collected qualitative data, the measurement tool -a researcher-made questionnaire- was constructed to measure the variables in the research. To ensure content validity, a thorough review of the literature on the subject of the research was conducted. The questionnaire was also evaluated by a pilot study. A panel of experts (professors and tax experts) reviewed it, after which necessary changes were made to improve both the content 
and clarity of the questionnaire. Internal consistency was calculated using Cronbach's alpha and composite reliability. Thirty questionnaires were distributed twice with the interval of 10 days between the taxpayers of different clusters. The data was collected from February 2018 to June 2018. The respondents were asked to evaluate the selected variables on a five-point Likert scale. The statistical population comprises 26500 individual business taxpayers in tax offices in Mazandaran province of Iran and 379 of them were chosen as the sample size using Cochran's formula with an alpha level of .05. In the second step, in order to test the conceptual model, quantitative data was collected through descriptive-survey research methodology on the impact of accountability on the legitimacy and also, on the impact of legitimacy on the voluntary compliance of taxpayers. From 379 questionnaires distributed, a total of 334 questionnaires were returned. The average variance of the variables was also extracted to calculate convergent validity. Partial least squares path modeling was used by Smart PLS software to examine the measurement and structural models, and the hypothesis test. In this section, all the statistical operations performed on the questionnaire were presented in the form of categorization. Student's t-test and SPSS software were also used to examine the status of model variables.

\section{Results}

Findings gathered about the first question of the research, with a thorough examination of the research literature, was analyzed and then classified into four categories, described in Table 3:

Table 3

The Legitimate Expectations and Demands of Taxpayers from Policymakers, Tax Managers, and Other Tax Officials

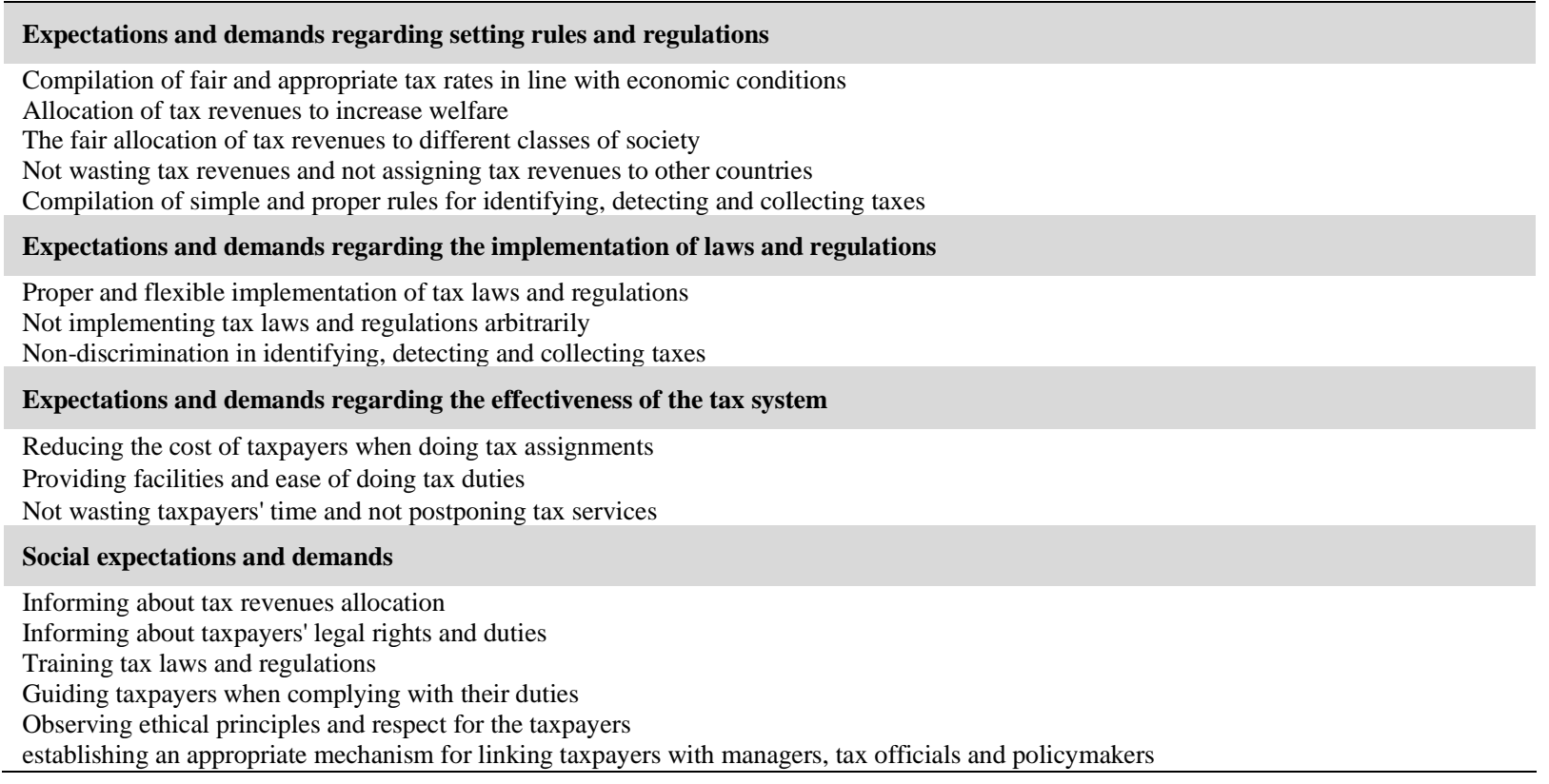

By analyzing the findings of the first question and the research literature, using the classification of Bovens' accountability Types (2007), four types of political, managerial, legal, and social accountability mechanisms were identified based on the nature of the accountability forum, as presented in Table 4: 
Table 4

Accountability Mechanisms in the Tax System

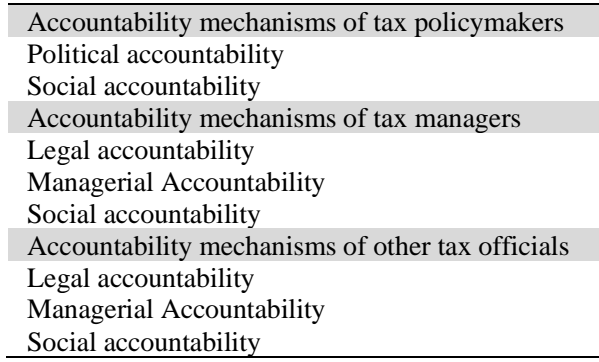

To test the proposed research model, data analyses for both the measurement and structural model were performed using Partial Least Squares (PLS). PLS analyzes structural equation models, including measurement and structural models with multi-item variables that contain direct, indirect, and interaction effects (Kim, Ferrin, \& Rao, 2003). The combined analysis of the measurement and the structural model enables measurement errors of the observed variables to be analyzed as an integral part of the model, and factor analysis to be combined in one operation with hypothesis testing (Gefen, Straub, \& Boudreau, 2000).

\section{Measurement Model Assessment}

To assess the measurement model and convergent validity, the Average Variance Extracted (AVE) and the Composite Reliability (CR) have been used. Table 5 shows the significance of the average variance extracted, the composite reliability scores and Cronbach's alpha $(\alpha)$ of the main variables of the research:

Table 5

The Average Variance Extracted, Composite Reliability and Cronbach's Alpha

\begin{tabular}{lccc}
\hline Variables & AVE & CR > 0.7 & $\alpha$ \\
\hline accountability & .50 & .79 & .75 \\
Legitimacy & .51 & .79 & .74 \\
voluntary tax compliance & .64 & .78 & .76 \\
\hline
\end{tabular}

AVE should be greater than 0.5 to be considered adequate (Fornell \& Larcker, 1981). The AVE can be used to evaluate convergent validity. All AVE values of constructs were greater than 0.50, indicating convergent validity among variables. The Cronbach reliability coefficients of all variables were greater than 0.70 , the minimum cutoff score to be an acceptable reliability coefficient (Sanotos, 1999). Unlike the Cronbach's alpha, which implicitly assumes that each item carries the same weight, the composite reliability relies on the actual loadings to construct the factor score and is thus a better measure of internal consistency (Kim et al., 2003). All of the composite reliabilities of constructs had a value greater than 0.7 , indicating acceptable internal consistency (Gefen et al., 2000) which shows the appropriateness of the research instrument and acceptable measurement model fit. Recently, it has been proposed the Heterotrait-monotrait ratio of the correlations (HTMT) approach to assess discriminant validity (Henseler, Ringle \& Sarstedt, 2015). The HTMT test indicated that all variables pairs had HTMT less than 1, which shows that there is a discriminant validity.

The Confirmatory Factor Analysis (CFA) was conducted separately at the level of individual items and measurement models to examine if the data confirm and specify the hypothesized model. 
All observed variables or items were significantly $(\mathrm{p}<.05)$ loaded on their corresponding factors (i.e. accountability, Legitimacy, and voluntary tax compliance). The CFA showed that the accountability, Legitimacy, and voluntary tax compliance models had good model fit. The two incremental fit indices Comparative Fit Index (CFI) and the Non-Normed Fit Index (NNFI) as indices of comparative fit were above .90. The Root Mean Square Error of Approximation (RMSEA) and Chi-square/df as indices of absolute fit were below .08 and less than 3 respectively. The fit indices for accountability model was NNFI $=.94, \mathrm{CFI}=.91, \mathrm{RMSEA}=.05$, and $\chi 2 / \mathrm{df}=$ $2.22(\mathrm{p}<.05)$. The fit indices for Legitimacy model was NNFI $=.91, \mathrm{CFI}=.92$, RMSEA $=.06$, and $\chi 2 / \mathrm{df}=1.81(\mathrm{p}<.05)$. The fit indices for voluntary tax compliance model was NNFI $=.98, \mathrm{CFI}$ $=.95$, RMSEA $=.07$, and $\chi 2 / \mathrm{df}=1.71(\mathrm{p}<.05)$.

\section{Structural Model Assessment}

In this step, the model's predictive capabilities and the relationships between the constructs were considered. The structural model was examined in terms of $\mathrm{R}^{2}$ and $\mathrm{Q}^{2}$, T-statistic value, and Path coefficient.

Table 6

$R 2$ and $Q 2$ Values Of Dependent Variables

\begin{tabular}{lcccc}
\hline Dependent construct & $\mathrm{Q}^{2}$ & Inference & $\mathrm{R}^{2}$ & Inference \\
\hline Legitimacy & .69 & High predictive relevance & .70 & High predictive accuracy \\
Voluntary tax Compliance & .85 & High predictive relevance & .86 & High predictive accuracy \\
\hline
\end{tabular}

In PLS path models, the squared correlation values of $.67, .33$, and .19 are considered substantial, moderate, and weak, respectively (Chin, 1998). The $\mathrm{R}^{2}$ value of each latent endogenous construct, as shown in Table 6, is greater than .67 and the values are considered to be substantial. The quality of partial least squares path model is evaluated by calculating $Q^{2}$ statistics. It is the capability of the model to predict by repeating the observed values by the model itself through blindfolding procedures (Shanmugapriya \& Subramanian, 2015). Q ${ }^{2}$ greater than zero means the model has predictive relevance and less than zero means the model lacks predictive relevance. Values of .02, .15 , and .35 indicate that an exogenous construct has a small, medium, or large predictive relevance for a selected endogenous construct (Chin, 1998). Accordingly, the $\mathrm{Q}^{2}$ value as shown in Table 6 indicates the path model's predictive relevance for dependent constructs.

\section{GOF Index}

Goodness of Fit (GoF) index is defined as the geometric mean of the average communality and average R2 for all endogenous constructs (Tenenhaus et al. 2005). According to Chin et al. (2010, p. 680), "The intent is to account for the PLS model performance at both the measurement and the structural model with a focus on overall prediction performance of the model. Cohen (1988) suggests GoF small (0.10), GoF medium (0.25) and GoF large (0.36). For the model depicted in Fig. 2, this study obtains a GoF value of 0.412 , which exceeds the cut-off value of 0.36 for large effect sizes of R2 (Cohen 1988). It indicates that the model has a high prediction power and good internal model fit. 


\section{Test of the Third and Fourth Questions of the Research}

In this section, Path analysis and levels of significance are used in assessing the hypothesized associations of the research. The path coefficients represent the expected change in the endogenous construct for a unit change in a predictor construct. For assessing the significance of the hypothesis, the non-parametric bootstrapping procedure was used (Chin, 1998). The results of PLS provide student's t-test to be performed for the significance of the path coefficients. Using a two-tailed ttest with a significance level of .05, the path coefficient will be significant if the T-statistics is larger than 1.96 (Wong, 2013). To answer the third and fourth questions of the research, first, the impact of the overall tax system's accountability on the legitimacy and then the impact of the legitimacy on voluntary tax compliance was tested.

As presented in Table 7, the overall tax system's accountability had a positive impact on the legitimacy and there was a high correlation between these two variables, $\beta=.83, t=19.21$. Moreover, the legitimacy had a positive impact on voluntary tax compliance and there was a moderate correlation between these two variables, $\beta=.56, t=7.73$.

Table 7

Results of Path Coefficients and T-value

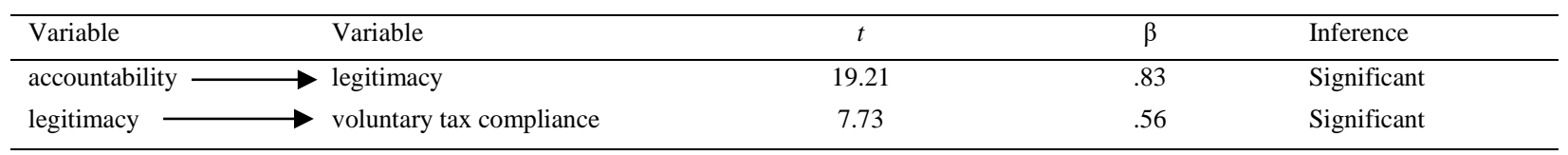

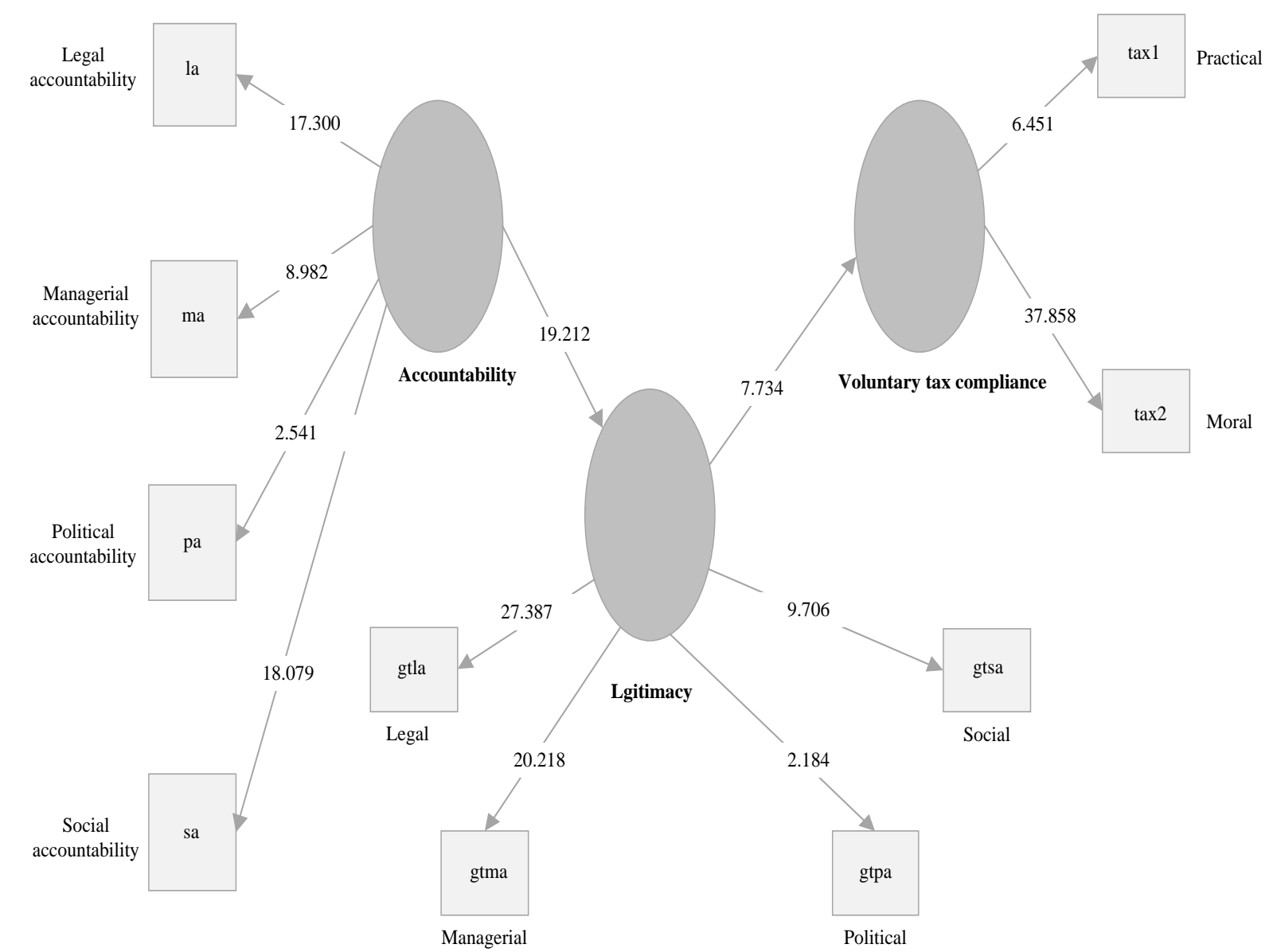

Figure 2. T-values of variables 


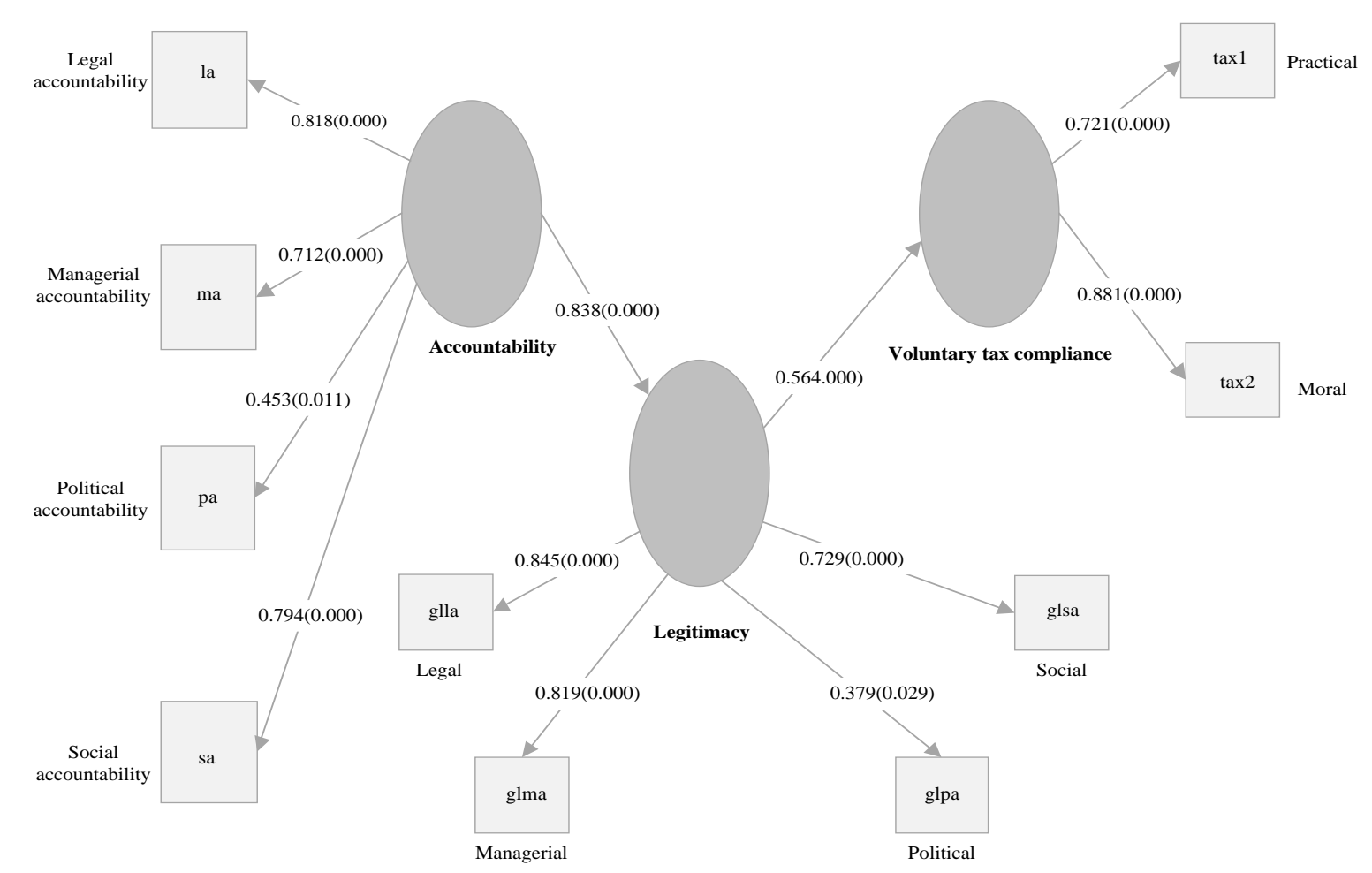

Figure 3. Path coefficients of variables

In order to more accurately explain the variables of the model, the impact of each of the political, managerial, legal, and social accountability mechanisms on the corresponding political, managerial, legal, and social dimensions of legitimacy was tested. As shown in Table 8, the political $(t=33.28)$, legal $(t=7.35)$, managerial $(t=9.004)$, and social accountability $(t=22.65)$ mechanisms of the tax system had a positive effect on its corresponding dimension in legitimacy. Furthermore, as represented in Figure 4, there was a high correlation between each of the political, legal, managerial and social accountability mechanisms of the tax system and its corresponding dimension in legitimacy, $\beta=.91, \beta=.67, \beta=.70$, and $\beta=.81$, respectively. Also, the political dimension of legitimacy had a positive impact on voluntary tax compliance and a high correlation between independent and dependent variables, $\beta=.62, t=20.52$. Additionally, the social dimension of legitimacy had a positive effect on voluntary tax compliance and a weak correlation between these two variables, $\beta=.27, t=5.81$. The managerial $(t=.64)$ and legal dimensions of legitimacy $(t=.91)$ did not have a significant impact on voluntary tax compliance.

Table 8

Results of Path Coefficients and T-value

\begin{tabular}{llcll}
\hline Variable & \multicolumn{1}{c}{ Variable } & $t$ & $\beta$ & Inference \\
\hline political accountability & $\longrightarrow$ political dimension of legitimacy & 33.28 & 0.91 & Significant \\
political dimension of legitimacy & voluntary tax compliance & 20.52 & 0.62 & Significant \\
managerial accountability & managerial dimension of legitimacy & 9.00 & 0.70 & Significant \\
managerial dimension of legitimacy & $\longrightarrow$ voluntary tax compliance & 0.64 & --- & insignificant \\
legal accountability & legal Dimension of legitimacy & 7.35 & 0.67 & Significant \\
legal dimension of legitimacy & voluntary tax compliance & 0.91 & --- & insignificant \\
social accountability & Social Dimension of legitimacy & 22.65 & 0.81 & Significant \\
social dimension of legitimacy & voluntary tax compliance & 5.81 & 0.27 & Significant \\
\hline
\end{tabular}




\section{Status of the Research Variables}

To study the status of each variable in the research, one-sample T-test was used. According to the intended range of responses, the test value was considered 3. If the average of replies in each of the variables is more than 3 , the status of the variable will be at an optimal level. Also, a confidence level of $95 \%$ was chosen. If the absolute value of the calculated statistics has a value greater than the critical value, then the null hypothesis, $\mathrm{H}_{0}$ should be rejected and the alternate hypothesis, $\mathrm{H}_{1}$ is assumed to be correct.

According to the $t$-statistics values shown in Table 9, the managerial accountability at $(t=8.73)$ and legal accountability $(t=4.22)$ were greater than the obtained critical value at 1.64; thus the null hypothesis, $\mathrm{H}_{0}$ was rejected and this means these two variables are at an optimal level. Also, according to the $t$-statistics values, political accountability $(t=-20.22)$ and social accountability $(t$ $=-9.69)$ were not greater than the obtained critical value at 1.645 ; thus the null hypothesis, $\mathrm{H}_{0}$ was not rejected and this means these two variables are not at an optimal level. The findings also indicated that the $t$-statistics value of the overall accountability of the tax system $(t=-2.02)$ was not greater than the obtained critical value at 1.64; thus the null hypothesis, $\mathrm{H}_{0}$ was not rejected and this means the variable is not optimal. Furthermore, the findings indicated that the $t$-statistics value of legitimacy $(t=-1.67)$ was not greater than the obtained critical value at 1.64 ; thus, the null hypothesis, $\mathrm{H}_{0}$ was not rejected and this means, in general, this variable is not optimal. Also, according to $t$-statistics values, the political and social dimensions of legitimacy $(t=-21.54)$ and $(t$ $=-11.76$ ), were not greater than the obtained critical value at 1.64; thus the null hypothesis, $\mathrm{H}_{0}$ was not rejected and this means these two variables are not optimal. The $t$-statistics values of managerial and legal dimensions of legitimacy $(t=9.68)$ and $(t=5.04)$ were greater than the obtained critical value at 1.64; thus the null hypothesis, $\mathrm{H}_{0}$ was rejected and this means these two variables were optimal. The findings also indicated that the $t$-statistics value of voluntary tax compliance $(t=-$ 17.81) was not greater than the obtained critical value at 1.64; thus, the null hypothesis, $\mathrm{H}_{0}$ was not rejected and this means that this variable is not optimal.

Table 9

Results of one-sample t-test

\begin{tabular}{|c|c|c|c|c|c|c|}
\hline \multirow[t]{2}{*}{ Test Value $=3$} & \multirow[b]{2}{*}{$t$} & \multirow[b]{2}{*}{$d f$} & \multirow[b]{2}{*}{$p$} & \multirow[b]{2}{*}{ Mean Difference } & \multicolumn{2}{|c|}{ 95\% Confidence Interval of the Difference } \\
\hline & & & & & Lower & Upper \\
\hline Political Accountability & -20.22 & 333 & .00 & -.61 & -.67 & -.55 \\
\hline Managerial Accountability & 8.73 & 333 & .00 & .46 & .35 & .56 \\
\hline Legal Accountability & 4.22 & 333 & .00 & .24 & .13 & .35 \\
\hline Social Accountability & -9.69 & 333 & .00 & -.31 & -.37 & -.24 \\
\hline Overall Accountability & -2.02 & 333 & .04 & -.05 & -.10 & .00 \\
\hline Political Dimension of legitimacy & -21.54 & 333 & .00 & -.56 & -.61 & -.51 \\
\hline Managerial Dimension of legitimacy & 9.68 & 333 & .00 & .58 & .46 & .70 \\
\hline Legal Dimension of legitimacy & 5.04 & 333 & .00 & .35 & .21 & .49 \\
\hline Social Dimension of legitimacy & -11.76 & 333 & .00 & -.35 & -.41 & -.29 \\
\hline Overall legitimacy & -1.67 & 333 & .09 & -.06 & -.14 & .01 \\
\hline Voluntary Tax Compliance & -17.81 & 333 & .00 &.-.94 & -1.04 & -.83 \\
\hline
\end{tabular}




\section{Discussion and Conclusion}

This study examined the impact of the tax system's accountability on improving taxpayers' voluntary tax compliance through influencing taxpayers' perceived legitimacy of the tax system. According to the results of the analysis, the overall tax system's accountability had a positive impact on the legitimacy and there was a high correlation between these two variables. These results were in line with the findings of the studies found in the literature (Koppel, 2010; Wareman, 2013) who examined the effect of the transparency concept of accountability on legitimacy. As shown in Table 1 , informing about tax revenues allocation, as well as taxpayers' legal rights and duties, is related to the concept of transparency. According to the results of the analysis, the legitimacy had a positive impact on voluntary tax compliance. This result was in parallel with the findings of Jagers et al. (2017) who concluded that legitimacy was indeed important in explaining policy support. The results also indicated the positive impact of the political and social dimension of legitimacy on voluntary tax compliance. This result was consistent with Levi et al. (2009), Gobena, (2017), and Van Dijke et al. (2019) who concluded procedural and distributive justice provide an encompassing index of the legitimacy of tax authorities and enhance voluntary tax compliance.

The impact of accountability as 'responsiveness'on legitimacy has been investigated for the first time in the present study, although pursuing the wishes or needs of the citizens in this type of accountability covers with the other various distinct concepts of accountability such as transparency, mentioned in the literature (Koppel, 2010; Wareman, 2013). This research also presents a novel classification of the concept of legitimacy different from the studies found in the literature. Corresponding to the four types of accountability identified, the authors developed four political, managerial, legal, and social dimensions of legitimacy and defined legitimacy as the acceptance and approval of the tax system's procedures or tax authorities' activities when doing their social, managerial, political, and legal duties. The authors assume that each type of accountability affects its respective dimension in legitimacy.

The findings of the research indicated the differences in the legitimate expectations and demands of taxpayers so that responding to the legitimate expectations and demands of taxpayers regarding setting rules and regulations are solely the responsibility of tax policymakers. Also, expectations and demands for information and appropriate mechanisms of communication with taxpayers, classified as part of the social expectations and demands, can be grouped among taxpayers' legitimate expectations and demands from tax policymakers. On the other hand, the legitimate expectations and demands from managers and other tax officials who are in the administrative sector of the tax system, although slightly different from each other, include expectations and demands regarding the effectiveness and proper enforcement of laws and regulations, and also informing and establishing appropriate communication mechanisms with taxpayers, guidance and education, and preserving the dignity of taxpayers which are classified as social expectations and demands. The findings show to achieve overall accountability, the legitimate expectations and demands of taxpayers from both "political" and "administrative" sectors of the tax system should be taken into account.

The findings indicated that the optimality of managerial and legal accountability in the administrative sector of the tax system does not have a significant impact on voluntary tax compliance. It can be concluded that the overall accountability of the tax system is not at an optimal level because, in order of importance, political accountability and then social accountability in the tax system are not at the optimal level. 
Findings also indicated the positive impact of the tax system's overall accountability on the legitimacy and a strong correlation between these two variables. Regarding the lack of optimality level in political and social dimensions of legitimacy and the optimality level of managerial and legal dimensions of this variable, it can be concluded that, in general, lack of optimality in legitimacy, in order of importance, is because its political and social dimensions are not at an optimal level.

The findings of the research indicated the positive impact of the political dimension of legitimacy on voluntary tax compliance and the existence of a high correlation between these two variables. The findings also indicated the positive impact of the social dimension of legitimacy on voluntary tax compliance and the existence of a weak correlation between these two variables. Furthermore, the findings indicated an insignificant impact of the legal and managerial dimensions of legitimacy on voluntary tax compliance. Therefore, it can be concluded that despite the optimal level of managerial and legal accountability, in the absence of the optimal level of political and social accountability mechanisms, the political and social dimensions of legitimacy has not been at an optimal level and thus this has made voluntary tax compliance status far from the optimal level.

The findings indicated that managerial and legal accountability had a positive impact on the managerial and legal dimensions of legitimacy but these two dimensions did not have a significant impact on voluntary tax compliance, which is due to the lack of optimality of political and subsequently social accountability. It can be concluded that since the political accountability was not at the optimal level, the optimality of managerial and legal accountability could not have a significant impact on voluntary tax compliance in tax offices in Mazandaran province of Iran. The positive impact of the political dimension of legitimacy on voluntary tax compliance and the existence of a high correlation between these two variables reveal the importance of political accountability and its impact on the current unfavorable status of voluntary tax compliance. Therefore, according to the conclusions made based on the findings of the research, the following implications and suggestions are provided:

1. To promote legitimacy, and as a result, to increase voluntary tax compliance in the tax system, the administrative and political sectors of the tax system should be considered simultaneously. Expectations from the administrative sector of the tax system, by improving procedures and processes, as well as the proper implementation of laws and regulations, to promote taxpayers' perceived legitimacy and thereby to increase voluntary tax compliance, will not be fruitful. In the current situation, more attention should be paid to the legitimate expectations and demands of taxpayers from policymakers regarding the establishment of the laws and regulations presented in Table 3.

2. Political accountability is the most important factor affecting taxpayers' perceived legitimacy, and as a result, voluntary tax compliance. In the current situation, this is a strengthening of democracy and a response to the legitimate expectations and demands of taxpayers from policymakers, which can increase the voluntary tax compliance and ultimately tax collection. Therefore, free and democratic elections, which are the most important political accountability tools, must be institutionalized in the community and be given greater consideration by the authorities so that the voices of citizens and their legitimate expectations and demands are reflected in the public policies.

3. Social accountability is an important part of overall accountability in the tax system. Politicians, as tax policymakers, although not directly accountable until the next election, should be sensitive 
to the demands and expectations of taxpayers in their term of office. They should be responsive to the social demands of voters by establishing appropriate communication channels, transparency in the dissemination of information, respect for the demands of the guilds, etc. Also, in the administrative sector, managers and other tax officials responsible for policy implementation must, in addition to legal and managerial accountability, be sensitive to the legitimate expectations and demands of taxpayers in establishing appropriate communication channels, informing, educating, and respect, and should not limit their duties solely to improving the effectiveness and proper implementation of laws and regulations.

4. The present study was limited to the individual business taxpayers in tax offices in Mazandaran province and for more generalizability of the research, it is suggested that other tax offices, especially in metropolitan areas, as well as taxpayers in other sources, be tested. Another suggestion is related to the statistical population of the research. Not all taxpayers may have the ability to analyze questionnaires. It is recommended that this study be conducted only by educated taxpayers or tax officials who interact directly with taxpayers.

\section{References}

Aboagye. P. Y., \& Hillbom, E. (2020). Tax bargaining, fiscal contracts, and fiscal capacity in Ghana: A long-term perspective. African Affairs, 119(475), 177-202.

Akpanuko, E. E., \& Asogwa, I. E. (2013). Accountability: A synthesis. International Journal of Finance and Accounting, 3(2), 164-173.

Allingham, M. G., \& Sandmo, A. (1972). Income tax evasion: A theoretical analysis. Journal of Public Economics, 1(3-4), 323338.

Andreoni, J., Erard, B., \& Feinstein, J. (1998). Tax compliance. Journal of Economic Literature, 36(2), 818-860.

Bamforth, N., \& Leyland, P. (2013). Accountability in the Contemporary Constitution. Oxford: Oxford University Press.

Batranchea, M., Nichita, R., Batranchea, L., \& Moldovan, A. B. (2012). Tax compliance models: From economic to behavioural approaches. Transylvarian Review of Administrative Sciences, 8(36), 13-26.

Becker, G.S. (1968). Crime and punishment: An economic approach. Journal of Political Economy, 76(2), 169-217.

Bovens, M. (2007). Analysing and assessing accountability: A conceptual framework. European Law Journal, 13(4), 447-468.

Bovens, M. (2010). Two Concepts of accountability: Accountability as a virtue and as a mechanism. West European Politics, 33(5), 946-967.

Brandsma, G. J., \& Schillemans, T. (2013). The accountability cube: Measuring accountability. Journal of Public Administration Research and Theory, 23(4), 953-975.

Brown, L. D., \& Jagadananda, K. (2007). Civil Society Legitimacy and Accountability: Issues and Challenges. Cambridge, MA: The Hauser Center for Nonprofit Organizations, John F. Kennedy School of Government, Harvard University.

Chin, W.W. (1998). The partial least squares approach to structural equation modeling. In G. A. Marcoulides (Ed.), Modern methods for business research (pp. 295-336). Mahwah, NJ: Lawrence Erlbaum Associates.

Cohen, J. (1988). Statistical Power Analysis for the Behavioral Sciences. Hillside, NJ: Lawrence Erlbaum.

Deephouse, D. L., \& Carter, S. M. (2005). An examination of differences between organizational legitimacy and organizational reputation. Journal of Management Studies, 42(2), 329-360.

Di John, J. (2006). The political economy of taxation and tax reform in developing countries. WIDER Research Paper, $2006 / 74$. Helsinki: UNU-WIDER.

Fornell, C., \& Larcker, D. F. (1981). Evaluating structural equation models with unobserved variables and measurement error. Journal of Marketing Research, 18(1), 39-50.

Gangl, K., Hofmann, E., \& Kirchler, E. (2015). Tax authorities' interaction with taxpayers: A conception of compliance in social dilemmas by power and trust. New Ideas in Psychology, 37, 13-23. 
Gefen, D., Straub, D. W., \& Boudreau, M. (2000). Structural equation modeling and regression: Guidelines for research practice. Communications of the Association for Information Systems, 4(1), 7.

Gezelius, S. S. (2002). Do norms count? State regulation and compliance in a Norwegian fishing community. Acta Sociologica, 45(4), 305-314.

Gobena, L. B. (2017, December 15). Towards integrating antecedents of voluntary tax compliance (No. EPS-2017-436ORG). ERIM Ph.D. Series Research in Management. Erasmus University Rotterdam. Retrieved from http://hdl.handle.net/1765/103276

Henseler, Jö., Ringle, C. M., \& Sarstedt, M. (2015). A new criterion for assessing discriminant validity in variance-based structural equation modeling. Journal of the Academy of Marketing Science, 1-21

Honneland, G. (2000). Compliance in the Barents Sea fisheries. How fishermen account for conformity with rules. Marine Policy, 24(1), 11-19.

Jagers, S., Matti, S., \& Nordblom, K. (2016). How policy legitimacy affects policy support throughout the policy cycle. $Q o G$ Working Paper Series, 15, 1-30.

Kaplan, S. E., \& Ruland, R. G. (1991). Positive theory, rationality, and accounting regulation. Critical Perspectives on Accounting, 2(4), 361-374.

Kim, D. J., Ferrin, D. L. \& Rao, H. R. (2003). Antecedents of consumer trust in B-to-C electronic commerce. Paper presented at the Americas Conference on Information Systems (AMCIS), Tampa, Florida.

Koppell, J. G. S. (2005). Pathologies of accountability: ICANN and the challenge of multiple accountabilities disorder. Public Administration Review, 65(1), 94-107.

Koppell, J. G. S. (2010). World Rule, accountability, legitimacy, and the design of global Governance. Chicago, IL: University of Chicago Press.

Levi, M., Sacks, A., \& Tyler, T. (2009). Conceptualizing legitimacy, measuring legitimating beliefs. American Behavioral Scientist, 53(3), 354-375.

Marvin, S. D., Marilou, L. M., \& Max, T. Q. (2017). Agent-based modelling of pragmatic legitimacy as organizational conflict control. IOSR Journal of Humanities and Social Science, 22(5), 63-68.

Modugu, P. K., Eragbhe, E., \& Izedonmi, F. (2012). Government accountability and voluntary tax compliance in Nigeria. Research Journal of Finance and Accounting, 3(5), 69-76.

Muehlbacher, S., Kirchler, E., \& Schwarzenberger, H. (2011). Voluntary versus enforced compliance: Empirical evidence for the "slippery slope" framework. European Journal of Law and Economics, 32(1), 89-97.

Mulgan, R. (2000). Accountability: An ever-expanding concept? Public Administration, 78(3), 555-573.

Murphy, K., Bradford, B. \& Jackson, J. (2016). Motivating compliance behavior among offenders: Procedural justice or deterrence? Criminal Justice and Behavior, 43(1), 102-118.

Rached, D. H. (2016). The concept(s) of accountability: form in search of substance. Leiden Journal of International Law, 29(2), 317-342.

Rolle, D. (2017). What makes citizens satisfied? The influence of perceived responsiveness of local administration on satisfaction with public administration. Journal of Social and Administrative Sciences, 4(1), 1-13.

Romzek, B. S., \& Dubnick, M. (1994). Issues of accountability in flexible personnel system. In P. W. Ingraham \& B. S. Romzek (Eds.), New paradigms for government: Issues for the changing public service (pp. 263-294). San Francisco: Jossey-Bass.

Roth, J. A., Scholtz, J. T., \& Witte, A. D. (1989). Taxpayer compliance: An agenda for research. Philadelphia. University of Pennsylvania Press.

Santos, J. R. A. (1999). Cronbach's alpha: A tool for assessing the reliability of scales. Journal of extension, 37(2), 1-5.

Scharpf, F. W. (2003). Problem-solving effectiveness and democratic accountability in the EU. MPIfG Working Paper, 03/1.

Schedler, A., Diamond, L. J., \& Plattner, M. F. (Eds.) (1999). The self-restraining state: power and accountability in new democracies. United States: Lynne Rienner Publishers.

Shanmugapriya, S., \& Subramanian, K. (2015). Structural equation model to investigate the factors influencing quality performance in Indian construction projects. Sadhana-Academy Proceedings in Engineering Sciences, 40(6), 1975-1987.

Sinclair, A. (1995). The chameleon of accountability: Forms and discourses. Accounting Organizations and Society, 20(2/3), 219-237.

Stern, M. (2008). Coercion, voluntary compliance, and protest: The role of trust and legitimacy in combating local opposition to protected areas. Environmental Conservation, 35(3), 200-210.

Tenenhaus, M., Vinzi, V. E., Chatelin, Y-M., \& Lauro, C. (2005). PLS Path Modeling. Computational Statistics and Data Analysis, 48(1), 159-205. 
Tilahun, M. (2018). Economic and social factors of voluntary tax compliance: Evidence from Bahir Dar city. International Journal of Accounting Research, (6)2, 182.

Torgler, B. (2011). Tax morale and compliance: review of evidence and case studies for Europe. Policy Research Working Paper, 5922, Washington, D. C: The World Bank.

Tyler, T. R. (1990). Why people obey the law. New Haven, CT, USA: Yale University Press.

Tyler, T. R. (2006). Psychological perspectives on legitimacy and legitimation. Annual Review of Psychology, 57, 375-400.

Tyler, T. R., \& Fagan, J. (2008). Legitimacy and cooperation: Why do people help the police fight crime in their communities? Ohio State Journal of Criminal Law, 6, 231-275.

van Dijke, M., Gobena, L. B., \& Verboon, P. (2019). Make Me Want to Pay. A Three-Way Interaction Between Procedural Justice, Distributive Justice, and Power on Voluntary Tax Compliance. Frontiers in Psychology, 10(1632). https://doi.org/10.3389/fpsyg.2019.01632

Viteri, C. \& Chavez, C. (2007). Legitimacy, local participation, and compliance in the Galapagos Marine Reserve. Ocean and Coastal Management, 50(3/4), 253-274.

Wahl, I., Kastlunger, B., \& Kirchler, E. (2010). Trust in authorities and power to enforce tax compliance: An empirical analysis of the "slippery slope framework". Law and Policy, 32(4), 383-406.

Wareman, M. (2013). Does accountability influence organisational legitimacy? Legitimacy of Semipublic organisations in the Netherlands (Unpublished master's thesis). Tilburg University.

Wenzel, M., \& Jobling, P. (2006). Legitimacy of regulatory authorities as a function of inclusive identification and power over ingroups and outgroups. European Journal of Social Psychology, 36(2), 239-258.

Williams, C. (2007). Research methods. Journal of Business and Economic Research, 5(3), 65-72.

Wong, K. K. (2013). Partial least squares structural equation modelling (PLS-SEM) techniques using Smart PLS. Marketing Bulletin, 24(1), 1-32. 